\title{
Clínica Agrícola e Pecuária da UEMS na Feira do Produtor de Cassilândia-MS
}

\author{
Michelle Nunes Barcelos ${ }^{1}$ \\ Wilson Itamar Maruyama²
}

O trabalho de pequenos produtores rurais inseridos na agricultura familiar é importante para abastecer o comércio local com produtos diversificados do segmento agrícola e pecuário, mas carecem de conhecimentos da cadeia produtiva a partir de técnicas desde o manejo até a venda ao consumidor. Desse modo, o objetivo do projeto de extensão foi esclarecer as dúvidas e auxiliar os pequenos produtores de Cassilândia - MS, com conhecimentos científicos da área da Agronomia através de consulta de material didático, e o auxílio dos docentes da Unidade, atuando durante o funcionamento da Feira do Produtor de Cassilândia. Para o desenvolvimento das atividades foram realizadas perguntas aos produtores, sobre os principais problemas relacionados aos seus produtos e práticas comerciais, tais como ocorrência de pragas e doenças nas culturas cultivadas. Todo o procedimento foi realizado a partir de um questionário manuscrito inicial feito com os produtores, sendo minuciosamente lido e revisado para analisar sobre as causas de problemas, e solucioná-los o mais rápido possível com retorno ao produtor ou em sua área de produção agrícola. Foram realizadas visitas tanto em propriedades rurais quanto em quintais na zona urbana, com coleta de material para análises em laboratório e fotografias dos problemas encontrados, sendo também, orientados por docentes da Universidade (UEMS) e revisão de bibliografias. Durante esse procedimento de coleta de informações, assistindo aos problemas diretamente com os produtores, ocorreu pela presença tanto na venda quanto na produção de onde esses produtores obtém sua renda familiar. Após o esclarecimento aos produtores sobre as dificuldades por eles defrontadas, foi divulgada a melhor forma para solucionar o problema e garantir melhores resultados nas atividades de manejo, e assim chegar à meta pretendida, ou seja, obter a produtividade desejada.

PALAVRAS-CHAVE: Extensão, produtores rurais, assistência técnica.

\section{Clinical Agricultural And Cattle Breeding Of UEMS In The Producer's Fair At Cassilândia - MS}

The work included small farmers on family farms are important to supply the local market with diversified products in the farming industry, but lack of knowledge of the supply chain from management techniques from the sale to the consumer. Thus, the purpose of the extension project was to clarify the doubts and help smallholder Cassilândia - MS, with the area of agronomy scientific knowledge through consultation of textbooks, and the help of the teachers of the Unit, working during the operation of the Fair producer Cassilândia. For the development of activities to producers questions about the major issues related to its products and business practices, such as the occurrence of pests and diseases in crops grown were performed. The entire procedure was performed from an initial questionnaire done with farmers, being thoroughly revised to read and analyze the causes of problems, and solve them as quickly as possible to return to the producer or in its area of agricultural production with visits occurred both on farms and in backyards in urban areas. During this process of gathering information, attending to the problems directly with producers, occurred both in the presence and in the sale of production where the producers get their household income. After clarifying the producers about the difficulties they faced, was announced the best way to solve the problem and ensure better results in management activities, and reach the desired goal, ie to obtain the desired productivity.

KEYWORDS: Extension, farmers, technical assistance.

1 Acadêmica do Curso de agronomia da UEMS, Unidade Universitária de Cassilândia; E-mail: michelleuems@gmail.com; PIBEX - PROEC/UEMS.

2 Doutor do Curso de Agronomia da UEMS, Unidade Universitária de Cassilândia; E-mail: wilsonmaruyama@hotmail.com. 


\section{INTRODUÇÃO}

No Brasil existem órgãos governamentais que auxiliam a agricultura familiar, mas a articulação de caráter político-partidário sobre as administrações estadual e municipal tem divergências políticas, onde os latifundiários atuam de forma indireta na obtenção de votos e mão de obra dos pequenos produtores, onde estes recebem benefícios dos programas públicos, mas em contrapartida sofrem concorrência dos fazendeiros e tempo limitado para dedicar à própria terra, existem aqueles produtores que não participam desses acordos políticos ficam carentes de assistência técnica, capacitação, representações sociais e recursos financeiros. (FABRE, 2010).

A agricultura familiar é responsável por $1 / 3$ do agronegócio brasileiro na produção agropecuária. Participando da riqueza nacional e dos vários nichos de mercado superando as dificuldades como a insuficiência de terras, créditos bancários, insuficiência de mão de obra qualificada, pouca tecnologia e falta de assistência técnica. (GUILHOTO et tal, 2006).

A comercialização dos produtos dos pequenos produtores é realizada em grande maioria através da venda na Feira do Produtor, buscando aderir maior valor em relação ao preço pago pelos supermercados e mercearias, pois a pequena quantidade produzida e pouca diversificação, além de pouco ou nenhum valor agregado como emprego de embalagens, podem ser desvalorizados pelos agentes intermediários da cadeia produtiva, onde estes buscam comprar em grande quantidade a baixos preços. (VENTURA et tal, 2012).

O trabalho de estudantes voluntários para prestar assistência técnica aos pequenos produtores se faz importante, devido às condições sócio econômicas que impedem de terem o seu acesso aos conhecimentos da área agropecuária e sem perspectivas para realizarem suas atividades no campo, sendo as alternativas e programas realizados pelos universitários uma forma de promover o desenvolvimento rural. (PEREIRA et tal, 2003).

\section{MATERIAL E MÉTODOS}

O local de realização do projeto foi na Feira do Produtor de Cassilândia - MS. O projeto foi colocado em prática através do contato direto com os feirantes por meio de 
visitas aos domingos no período da manhã, sendo usada uma ficha de identificação com a finalidade de sanar dúvidas da área agronômica.

As visitas nos locais com cultivo de plantas de interesse agronômico ocorreu tanto na cidade, onde se cultiva em quintais e em vasos, como também em propriedades rurais. Para a execução do projeto foi necessário computador com acesso à internet para pesquisas, lápis, caneta, materiais xerografados, máquina fotográfica, além de consulta ao acervo de livros da biblioteca e ao Corpo docente do Curso de Agronomia, e utilização do laboratório de microscopia na Unidade Universitária de Cassilândia.

Contudo, alguns consumidores da Feira do Produtor pediram auxílio com plantas ornamentais em suas residências, ou ainda problemas em pomar em propriedade rural, onde também receberam visitas técnicas, ou seja, a assistência prestada não foi apenas para vendedores da feira.

Quadro 1. Ficha utilizada na Feira do Produtor para identificação dos problemas de interesse agronômico e impressas para material de pesquisa ou informação com as soluções das situações analisadas. Cassilândia (2013 e 2014).

Ficha de Atendimento ao Produtor/Comunidade
Nome do produtor:
Fone:
Data:
Endereço:
Problemas/Diagnóstico:
Solução:
Professor Consultado:
Literatura Consultada:
PROJETO: Clínica Agropecuária na Feira do Produtor em Cassilândia-MS.
Aluna: Michelle Nunes Barcelos.
Professor Orientador: Wison Itamar Maruyama
Duração: 2013 a 2014.

BARCELOS, 2014.

\section{RESULTADOS E DISCUSSÃO}

Revista Extensão em Foco, n 13, Jan/ Jul (2017) p. 2 - 22. 
À exemplo das situações observadas durante o projeto de extensão, os seguintes dados foram coletados conforme o modelo da ficha do quadro 1 :

\section{Fichas de Atendimento ao Produtor.}

\section{Problemas/Diagnóstico:}

a) Pimenteira apresenta os sintomas: folhas enroladas e de cor verde escura, improdutivas, galhos nus, raízes atrofiadas e pouca emissão de secundárias, pimentas com amadurecimento precoce, alguns galhos com superbrotamento ou "vassouramento" de folhas, a morte surge após a seca total da planta.

b) Couve: folhas com diferentes características como perfurações ou furos que atravessam as faces inferiores e superiores, deformação no formato, enrolamento nos cantos.

\section{Solução:}

a) A pimenteira está com situações em que houve excesso de tratamento com os produtos químicos usados (barrage mais diazenon), pois ocorreu o "vassouramento" em parte dos galhos devido à fitotoxidez, que pode ser feita uma poda. Enquanto que o caso com ausência de folhas e frutos, favorecendo a possibilidade da presença de virose nas plantas, confirmado pela tentativa de produzir mudas com sementes das plantas doentes, podendo ocorrer por um inseto vetor e aumentando a vulnerabilidade da planta com excesso de adubação e solos muito úmidos. As mudas devem ser feitas afastadas do local de plantio e com uso de sementes sadias, protegidas de vetores de doenças.

Evitar restos culturais no local de planto definitivo e esterco de origem animal que esteja contaminado com produtos químicos e microrganismos maléficos.

b) Na couve foi observada presença de pulgão que causam o enrolamento de partes das folhas com clareamento no seu interior, sendo necessário fazer controle químico com inseticidas e seguir orientações do rótulo do produto levando-se em conta o poder residual, ou, o controle natural (Receita A: folhas de arruda e água. Modo fazer: levar ao fogo com água fervente por 10 minutos, coar e aplicar depois de esfriar. Receita B: 30g de pimenta malagueta 1 litro de água. Modo de fazer: triturar no liquidificador com um pouco da água, coar e completar para 1 litro. Receita C: 4 dentes de alho 1 litro de água. Modo de fazer: esmagar os 4 dentes de alho e deixar curtir na água por 12 dias. Após este período, diluir em 10 litros d'água e pulverizar.). As lagartas que surgem no período noturno podem ser também eliminadas com caldas. (Numa garrafa de 1 litro, misture 50 $\mathrm{g}$ de fumo de rolo picado e pimenta malagueta. Complete com água e deixe repousar por uma semana. Dilua em 10 litros de água e pulverize.).

Revista Extensão em Foco, n 13 , Jan/ Jul (2017) p. 2 - 22. 
Conclui-se que nos dois casos pode ser feito o uso de neem contra pragas e doenças. $\mathrm{O}$ neem é uma planta do gênero Azadirachta e apresenta função pesticida, podendo ser utilizado sem riscos ambientais e à saúde humana no controle de pragas em culturas olerícolas.

Professor Consultado: $\operatorname{Prof}^{\mathrm{a}}$. Dr ${ }^{\mathrm{a}}$. Maria Luiza Nunes Costa.

\section{Literatura Consultada:}

PESAGRO-RIO (2005).

\section{Problemas/Diagnóstico:}

a) As pimenteiras produzidas em vaso estavam com encarquilhamento das folhas e deformação dos brotos. Isso está causando falta de desenvolvimento e produção no vegetal.

\section{Solução:}

a) As plantas de pimenta apresentavam infestação de pulgão verde. Portanto, devem ser tratadas com produtos naturais para não prejudicar a saúde da família, utilizando óleo de neem para pulverização nas partes aéreas semanalmente. Também, pode ser feito um método preventivo que evite o uso de agrotóxicos que pode tanto afetar a saúde humana se utilizado de modo incorreto, como causar efeito de resistência ao produto com aumento da população de insetos. A aplicação de inseticidas naturais como calda feita das folhas de fumo, alcachofra, neem, cravo-de-defunto, manjericão, girassol, hortelã, arruda e tomateiro, frutos de pimenta, semente de mostarda e fruta-do-conde, flores de calêndula, cebola, alho, citronela, xixi de vaca, entre outros produtos naturais, são alternativos e de baixo custo.

\section{Professor Consultado:}

Professoras: Prof ${ }^{a}$. Dr ${ }^{a}$. Maria Luiza Nunes Costa; Prof ${ }^{a}$. Dr ${ }^{a}$. Luciana Cláudia Toscano Maruyama.

\section{Literatura Consultada:}

AGRONOMIA.NET (2013).

\section{Problemas/Diagnóstico:}

a) As orquídeas estavam dentro de um xaxim em cima do tronco de árvore, apresentavam flores abortadas, escurecimento ou manchas pretas de algumas folhas velhas e jovens, brotos novos com raízes secas, as folhas tinham coloração verde clara.

\section{Solução:}

Revista Extensão em Foco, n 13, Jan/ Jul (2017) p. 2 - 22. 
a) A ocorrência da falta de adubação nas plantas pode ser resolvida com aplicações via raízes de NPK na formulação indicada para orquídeas plantas, favorecendo e dissolvido na água, seguindo o rótulo da embalagem, podendo ser aplicado parcelado e repetindo o tratamento a cada seis meses. O xaxim está com excesso de plantas, favorecendo a competição por nutrientes, luz solar e água; sendo importante que se faça o raleamento das orquídeas. Também, para prevenção de patógenos, pulverizar as folhas com produtos naturais, onde foi feito o uso de óleo de neem acrescido de água. Se algumas plantas continuarem com sintomas de apodrecimento, é devido à contaminação de fungos, principalmente, por causa, que a poda efetuada nas folhas com ferramenta infectada e sem passar algum produto preventivo na área cicatrizante, tem ocorrência corriqueira pelo dono das orquídeas. Assim, é importante que se faça uso de antifúngico de ação sistêmica, para orquídeas e a dose correta do rótulo do produto.

Professor Consultado: Prof ${ }^{\mathrm{a}}$. Dra ${ }^{\mathrm{a}}$. Maria Luiza Nunes Costa.

\section{Literatura Consultada:}

ARAÚJO (2013).

SEVERINO (2001).

\section{Problemas/Diagnóstico:}

a) A horta em um terreno da cidade está exposta diretamente aos fenômenos ambientais como chuva e insolação. Na época de seca, há falta de água na cidade e as plantas ficam ressecadas por causa do sol. Na época de muita umidade, ocorre excesso de água no solo e as plântulas de alface recém-transplantadas para o canteiro são afetadas pela força das gotas da chuva e ao encharcamento. O local é todo coberto com serragem para prevenir o ataque de lesmas. A utilização da calda feita de fumo ou mamona com Cloreto de Sódio é uma técnica preventiva contra insetos e sua aplicação favorece a obtenção de verduras e legumes com boa qualidade para a venda direta ao consumidor.

\section{Solução:}

a) A obtenção de um ambiente protegido para as hortaliças através de casas de vegetação com o uso de materiais como lona plástica transparente e tela de sombreamento, minimiza os efeitos de alguns agentes ambientes sendo os principais: a temperatura, velocidade do vento, radiação solar e umidade do ar. Portanto, plantas como a alface, que são mais sensíveis no período de verão, vão desenvolver e crescer de forma mais rápida, se comparada com aquelas desprotegidas, tendo assim maior qualidade da parte vegetativa com folhas mais macias e frescas.

Revista Extensão em Foco, nº 13, Jan/ Jul (2017) p. 2 - 22. 
Professor Consultado: Prof $^{\circ}$. Dr ${ }^{\circ}$. Wilson Itamar Maruyama.

\section{Literatura Consultada:}

BRITO (2000).

\section{Problemas/Diagnóstico:}

a) Os frutos de romã gigante, da espécie Punica granatum apresentam mancha escura ao redor do botão floral e apodrecimento. No interior da casca lesionada, a mucilagem em volta das sementes está com cor amarronzada com presença de larvas de mosca se alimentando.

\section{Solução:}

a) As manchas no fruto de romã são sintomas semelhantes da doença antracnose, ocasionada por fungos, que ataca a casca nos períodos do ano quando o clima está quente e úmido, favorecendo a sua infestação. $\mathrm{O}$ apodrecimento ocorre pela presença do fungo Botrytis, que penetra na parte inferior dos frutos, servindo de porta de entrada para a mosca das frutas depositarem os seus ovos no interior da casca, sendo notada pelas lagartas que se alimentam da polpa das sementes. Portanto, os frutos devem ser ensacados quando tiverem $2 \mathrm{~cm}$ de diâmetro. Também, pode se fazer armadilhas para as moscas com garrafa descartável PET e um substrato alimentar.

Confecção da armadilha: Em uma garrafa PET, recortar três janelas com $2 \mathrm{~cm}$ de altura e $1 \mathrm{~cm}$ de largura a partir de $10 \mathrm{~cm}$ de altura da garrafa. Colocar solução atrativa no seu interior, que pode ser: $25 \mathrm{ml}$ de proteína hidrolisada diluída em $475 \mathrm{ml}$ de água; $35 \mathrm{ml}$ de melaço de cana diluído em $465 \mathrm{ml}$ de água; suco de uva com água na proporção de 1:4 ou suco de pêssego com água de 1:10 respectivamente.

Professor Consultado: Prof ${ }^{\mathrm{a}}$. Dra ${ }^{\mathrm{a}}$. Maria Luiza Nunes Costa.

\section{Literatura Consultada:}

EMBRAPA (2006).

GLOBORURAL (2010).

\section{Problemas/Diagnóstico:}

a) Mamão com manchas escuras. Há a presença de doenças fúngicas antracnose e pinta preta.

a) Solução: A aplicação foliar com fungicida

Professor Consultado: Prof ${ }^{\mathrm{a}}$. Dr ${ }^{\mathrm{a}}$. Maria Luiza Nunes Costa. 


\section{Problemas/Diagnóstico:}

a) Pulgão branco na couve, rúcula e couve-flor. O produtor aplica o produto químico Barrage com extrato das folhas de arruda, confrei e fumo. A tentativa com o óleo de neem é pouco eficaz, pois após três dias os pulgões voltam para a horta.

a) Solução: Os pulgões observados eram alados, ou seja, o aumento da população de insetos com asas. Assim, para evitar a presença desses insetos, pode ser usada palha de arroz como cobertura dos canteiros, por apresentar ação refletora sobre eles, expulsando-os. Porém, o uso constante de produtos alternativos como inseticidas naturais, por exemplo, caldas a partir das folhas de fumo, óleo de neem ou Santa Bárbara por meio de pulverizações semanais, repelem os insetos evitando sua reprodução nas hortaliças e o uso de produtos agrotóxicos prejudiciais à saúde humana devido ao seu poder residual, que ocorre com a intenção de coibir essas populações de modo momentâneo e radical.

Professor Consultado: Prof ${ }^{\mathrm{a}}$. Dr ${ }^{\mathrm{a}}$. Luciana Cláudia Toscano Maruyama.

\section{Problemas/Diagnóstico:}

a) Os frutos de graviola estão com manchas escuras na casca e no seu interior contém brocas.

\section{Solução:}

a) Há diferentes maneiras para evitar o ataque de brocas nos frutos como a pulverização com inseticidas na época da frutificação; colocar sacos para proteção dos frutos no início do crescimento; usar iscas para a mosca-das-frutas.

Uma opção de isca: fazer janelas numa garrafa PET e no seu interior misturar suco de maracujá ou de pêssego com inseticida. Logo, as moscas vão morrer ao ficarem presas por causas das asas molhadas na substância, ou ainda, por intoxicação com o produto químico.

Professor Consultado: Prof $^{\mathrm{a}}$. Dr ${ }^{\mathrm{a}}$. Maria Luiza Nunes Costa.

\section{Problemas/Diagnóstico:}

a) A renda com a venda de geleias é pequena, pois é revendedora. A produtora sabe fazer as geleias, ou seja, tem a mão de obra e a matéria prima, porém falta possuir a máquina de fabricação.

b) Solução: A compra de uma máquina ou equipamento para fabricação de geleia de mocotó poderá aumentar a renda financeira e diversificar a produção de doces. Para Revista Extensão em Foco, n 13 , Jan/ Jul (2017) p. 2 - 22. 
início pode ser feita a compra de uma máquina mais em conta e de menor capacidade de produção, possibilitada por financiamento por programas de crédito para o incentivo da atividade familiar.

A montagem de uma Fábrica ou indústria de Geleia de Mocotó como todas as fábricas de alimentos, deve cumprir com o seguinte: Tem que ter espaço para manuseio e fabricação, a área poderá ser construída e ou adaptada para tal fabricação do produto. Deverá possuir licença para fabricação do produto e licenças ambientais. Alvará de funcionamento, aprovação no setor de bombeiros e todas as medidas de segurança para que trabalhadores possam desempenhar suas funções. Deverá também estar em dia com a parte tributária. Assim com toda documentação exigida para iniciar a produção o empreendedor poderá trabalhar sossegado. Os funcionários devem passar por treinamentos e noções de higiene para que possam manipular alimentos.

Os equipamentos que farão parte da fábrica deverão estar dispostos em uma lista detalhada e com as respectivas funções.

A geleia de Mocotó é de valor nutritivo muito grande, pois o mocotó é uma parte mole retirada de dentro do osso da perna ou parte do pé da vaca conhecido como tutano do pé do boi, quando cozido e adicionado ingredientes que farão a composição da geléia se torna de sabor agradável e apreciação de pessoas de todas as idades.

A geleia de mocotó tem valor proteico, mais a adição de ingredientes deixa o produto com bastante enriquecimento calórico.

Também é fonte de vitaminas e minerais que são muito enriquecedores para o funcionamento do sistema nervoso e previne contra o envelhecimento.

Esses ossos devem ser limpos e raspados para que possam passar pelo processo de corte e serrados são encaminhados a fervura e retirada da parte mole.

Devem ser cozido com água em alta temperatura em tachos de inoxidável e assim quando está morno é retirado dos ossos em seguida esse mocotó é batido em centrifugas industriais com açúcar e outros ingredientes como leite condensado deixando cremosa e quando esfria ela se solidifica.

Podem-se adicionar sabores como o de morango que é bem combinado a geleia. Com essência, sem adição de leite condensado ela também se torna de apreciação muito bem tolerada e envasada em potes de vidro pode ser complemento alimentar nutritivo.

É importante que os funcionários passem por treinamentos específicos e façam uso de uniformes, toucas e luvas para a fabricação da geleia de mocotó. Muitas receitas utilizando geleia de mocotó natural podem ser desenvolvidas algumas podem levar Revista Extensão em Foco, n 13 , Jan/ Jul (2017) p. 2 - 22. 
desde essências que incrementam mais o sabor, canela, noz moscada, cravo da índia e até a utilização de vinho, café e chocolate. Esse realce de sabor dependerá da receita empregada pelo empreendedor e pela aceitação do público.

A geleia é enformada em formas redondas ou quadradas e desenformadas após o resfriamento, embalada em embalagem própria para esse tipo de produto ou pode ser colocada em potes de vidro ou plástico.

Rotulado com todas as informações que forem necessárias para venda ao consumidor.

Nós poderemos lhe ofertar um projeto para a sua fábrica com capacidade de 100-200 $\mathrm{kg} /$ dia e se está pensando em grande, um projeto para 10.000-15.000 kg/ dia.

As secções principais deste projeto: Plataforma de recepção; Câmara de espera; Sala de elaboração; Sala de cozimento; Sala de embalagem; Depósito de embalagens; Câmara de estocagem; Expedição.

Este projeto conteria:

Projeto completo com arquivos para autocad (.dwg) da fábrica com:

Planta baixa da construção (Lay-out dos equipamentos; Cortes; Fachada; Planta de situação das construções no terreno; Planta dos escritórios, vestiários, refeitórios e outros anexos do empreendimento); Memorial básico da construção; Lista de equipamentos principais; Lista de fornecedores dos equipamentos não fabricados pela ENGENMAX; Lista de materiais da construção e orçamento da obra; Cronograma físico-financeiro da obra; Fluxograma de produção; Projeto em 3D.

O preço do projeto para uma fábrica de $100-200 \mathrm{~kg} / \mathrm{dia}$ é de $\mathrm{R} \$ 2.500$.

Professor Consultado: Prof $^{\circ}$. Dr ${ }^{\circ}$. Wilson Itamar Maruyama.

\section{Literatura Consultada:}

ZAMORANO (2014).

\section{Problemas/Diagnóstico:}

a) As orquídeas após a floração apresentam as folhas com manchas escuras, iniciando o ressecamento e morte.

\section{Solução:}

a) A separação das mudas para vasos maiores, evita a competição por nutrientes, água e luz, sendo importante que se faça uma adubação depois do transplante com um produto próprio para essa espécie e dose recomendada no rótulo, diluído em água. As folhas estão ressecadas devido ao ambiente, pois recebe excesso de radiação solar, onde afeta as orquídeas mais sensíveis. Portanto, algumas orquídeas sobrevivem em ambientes 
mais escuros, logo, deve ser feito testes com a mudança do ambiente até descobrir aonde se adaptam melhor.

Professor Consultado: Prof $^{\circ}$. Dro ${ }^{\circ}$ Etienné Groot.

\section{Problemas/Diagnóstico:}

a) As folhas de mexerica secam e caem.

b) As folhas de laranjeira estão amarelas e os frutos com grandes machas, onde no centro ficam na coloração amarronzada e ao redor amarelada.

c) As folhas de pequi estão com algumas verrugas.

d) As folhas das orquídeas apresentam galerias.

\section{Solução:}

a) Após ataque intenso de leprose, ocorre queda das folhas doentes. O controle é inapropriado nesse caso, visto que a copa está toda contaminada, o correto é efetuar a retirada da planta do pomar, para evitar que contamine as outras plantas.

b) Os sintomas apresentados são semelhantes à ocorrência pela doença leprose, causada por vírus e o inseto vetor é o ácaro. Portanto, como preventivo, deve ser feita a aplicação com acaricida para evitar o surgimento da doença. No controle da planta infectada, deve ser feita a poda nas partes lesionadas, e caso toda ter os sintomas, é importante que a plantas seja removida do local para que outras sadias não sejam contaminadas.

c) Um dos sintomas característicos de verrugose, doença provocada por fungos, é a deformação das folhas com lesões salientes e ásperas, de maior ocorrência em citros, mas foi observado nas folhas de pequi. $\mathrm{O}$ controle pode ser feito com fungicidas para evitar que a doença se propague nos frutos, de acordo com as doses recomendadas no rótulo do produto, pulverizando principalmente as brotações novas.

d) Os pulgões e as lagartas são insetos sugadores que podem atacar as folhas e deixar marcas nas folhas por onde se alimentam. O controle é feito com o uso de inseticidas próprios para esse tipo de planta.

Professor Consultado: Prof $^{\mathrm{o}}$. Dr ${ }^{\circ}$. Diógenes Martins Bardiviesso.

\section{Literatura Consultada:}

CPT (2000).

$\operatorname{UNESP}(2007)$.

\section{Problemas/Diagnóstico:}

Revista Extensão em Foco, n 13, Jan/ Jul (2017) p. 2 - 22. 
a) O cajuzeiro que foi plantado no pomar, depois de atingir 1 metro de altura, os galhos começaram a secar a partir do ápice, não produz frutos.

b) A árvore de limeira está com galhos secos.

c) A mangueira apresenta frutos com manchas pretas e folhas encarquilhadas.

d) A frutífera laranja da terra apresenta frutos pequenos e casca com coloração verde e amarelo claros na forma de listras, folhas cloróticas e começam a amarela nas bordas até a folha inteira.

e) Bananeiras apodrecem o colmo e cai com o peso do cacho.

f) O plantio de milho no pomar teve um crescimento de até $50 \mathrm{~cm}$ e sem produção de espigas.

g) Os frutos da jabuticabeira apresentam larvas no seu interior.

h) A árvore de mexerica Pocã está com os ponteiros dos galhos secos.

i) O limoeiro apresenta folhas com os insetos cochonilha, mosca branca e pulgão.

\section{Solução:}

a) A muda adquirida para ser implantada no pomar, provavelmente veio de algum viveiro com problemas fitossanitários, sendo observada a importância de procurar viveiros idôneos para adquirir mudas sadias. Porém, no pomar havia várias plantas adultas que causavam sombreamento em torno do cajueiro, podendo ser uma das causas da improdutividade, pois nas folhas e galhos não ocorreu a presença de sinais de patógenos.

b) Em pomares velhos, é recomendado fazer podas de renovação, principalmente em locais muito densos que atrapalham a passagem de radiação solar e ventilação, possibilitando a infestação de alguns patógenos como os fungos. A poda deve ser feita em bisel e passar calda bordalesa no ferimento, lembrando-se de eliminar os restos culturais para longe do pomar. Além disso, deve-se fazer a adubação de manutenção anualmente de acordo com a recomendação para o tipo de solo e região.

c) A antracnose é uma doença muito frequente em manga, causada por fungo e podendo hospedar outras espécies de plantas. O controle vai desde a aplicação de fungicidas até outras medidas como a eliminação de ramos doente, podas que propiciem o arejamento, limpeza do pomar, retirar frutos infectados das plantas, na pós-colheita aplica-se procloraz ou hidrotérmico à $52^{\circ} \mathrm{C}$ por cinco minutos.

d) A deficiência nutricional de plantas frutíferas pode causar má formação dos frutos e folhas com coloração irregular. Neste caso, as folhas apresentam sintomas de falta de 
Magnésio e os frutos a de Potássio. A recomendação para a fertilidade do solo deve ser feito pela análise de solo e pela idade do pomar, e estádio fenológico da planta.

e) O moleque-da-bananeira é uma das principais pragas da bananeira, onde o inseto é um besouro, cujas larvas constroem galerias no rizoma da planta (caule verdadeiro para armazenamento de reservas), tornando a planta sensível ao tombamento principalmente na época de frutificação, a planta tem seu crescimento limitado tanto da planta quanto dos frutos, sendo a propagação mais ocorrente é pelas mudas. No plantio da muda, deve-se fazer a limpeza do rizoma e depois tratar com inseticida específico em solução com água, sendo mergulhado por até 20 minutos e depois é efetuado o transplantio.

f) O plantio de milho no local da propriedade com características de solo arenoso foi feito sem antes fazer a correção de solo e as adubações de plantio e de manutenção. Além disso, o produtor deveria adquirir sementes de empresa idônea, bem armazenadas e com dentro do prazo de validade.

g) A mosca-das-frutas pode ser encontrada em diversas frutíferas na polpa dos frutos. Para o controle, devem ser retiradas dos frutos amadurecidos tanto da planta como aquele que caíram no chão, colocar iscas com inseticidas ou ainda aplicar o produto na planta após o florescimento.

h) A presença de propágulos de fungo nos galhos das árvores de mexerica foi observada durante a visita, tendo coloração branca. A aplicação de fungicida específico para o fungo em conjunto com tratos culturais como a poda, pode reduzir o ataque do fungo.

i) A presença desses insetos pragas no limoeiro, que podem hospedar diferentes espécies de plantas, pode ser feito o controlado com uso de inseticidas e iscas de cor amarela. O monitoramento da área é importante para conhecer a quantidade de infestação de pragas e observar o seu nível de controle. Porém, métodos preventivos podem ser implantados no pomar, como o uso semanal de produtos naturais, limpeza e retirada de restos culturais da área, dentre outros.

Professor Consultado: Prof $^{\mathrm{o}}$. Dr ${ }^{\circ}$. Wilson Itamar Maruyama.

\section{Literatura Consultada:}

EMBRAPA MANDIOCA E FRUTICULTURA (2005).

EMBRAPA SEMIÁRIDO (2012).

EMBRAPA SEMIÁRIDO (2007).

NOGUEIRA \& FERRARI (2009).

RAGA \& SOUZA FILHO (2007).

Revista Extensão em Foco, n 13 , Jan/ Jul (2017) p. 2 - 22. 


\section{Problemas/Diagnóstico:}

a) As roseiras apresentam manchas amareladas e escuras na face inferior e superior das folhas, causando a desfolha. O caule desenvolveu lesões púrpuras que se tornam pretas. b) Uma planta de flores cor vermelha, cujo nome Ixora, apresenta folhas cobertas por camada de coloração marrom e branca na nervura principal das folhas como se fosse algodão.

c) As folhas do cajueiro estão com manchas pequenas, arredondadas e de cor escuras em toda a superfície.

\section{Solução:}

a) A mancha preta em roseiras é uma doença fúngica que ataca principalmente na primavera, sendo importante fazer a retirada das folhas infectadas e descartá-las em local distante do roseiral. A poda dos ramos favorece a entrada de ar através deles, reduzindo o tempo de secagem após a irrigação e chuvas. Quando irrigar as roseiras, faça próximo ao chão para não espalhar a água nas folhas e propiciar disseminação do fungo. $\mathrm{O}$ uso de fungicida próprio para roseiras serve como controle químico, mas deve seguir as orientações no rótulo. Também, pode ser feita a adubação à base de NPK para melhorar o vigor das plantas.

b) A presença de cochonilha nas folhas de Ixora pode ser controlada por diferentes maneiras pela pulverização como: emulsões de sabão de coco ou detergente neutro e óleo mineral em seguida no período do final da tarde; ou ainda utilizar calda de fumo e de Santa Maria se o ataque estiver severo; aplicar inseticida de baixa toxicidade. Para o preparo da calda de fumo, misture $100 \mathrm{~g}$ do fumo cortado em $1 / 2 \mathrm{~L}$ de álcool, acrescente $1 / 2 \mathrm{~L}$ de água e deixe curtir por 15 dias. Depois corte $100 \mathrm{~g}$ de sabão neutro em pedaços e dissolva em $10 \mathrm{~L}$ de água. Misture as duas soluções e aplique sobre toda a plantas. No preparo da calda de Santa Maria, amoleça 200 g da erva em 1 L de água fria por 6 horas, aperte as folhas para extrair o suco e dilua o extrato em 5 litros de água, aplique no período de sol ameno. Apesar do controle natural ou químico de cochonilhas, é importante que seja feita a adubação das plantas, pois em estado de desnutrição ficam mais susceptíveis ao ataque de pragas e doenças.

c) O cajueiro está com a doença fúngica antracnose, que ocorre em épocas de umidade relativa do ar elevada. $\mathrm{O}$ controle pode ser feito através da aplicação de fungicidas e algumas práticas culturais para reduzir a infestação como: a poda de ramos doentes, retirada do excesso de ramos para propiciar arejamento, limpar o pomar de restos de cultura contaminados.

Revista Extensão em Foco, n 13 , Jan/ Jul (2017) p. 2 - 22. 
Professor Consultado: Prof $^{\mathrm{o}}$. Dr ${ }^{\mathrm{o}}$. Wilson Itamar Maruyama e $\operatorname{Prof}^{\mathrm{o}}$. Dr ${ }^{\mathrm{o}}$. Diógenes Martins Bardiviesso.

\section{Literatura Consultada:}

EDUCAÇÃO E CIÊNCIA (2014).

JARDINAGEM (2010).

EMBRAPA (2012).

\section{Problemas/Diagnóstico:}

a) As mudas de pepino são produtivos em apenas dois ciclos e morrem. As folhas ficam com manchas amareladas e amarronzadas até atingi-la inteira e depois seca toda a planta.

b) O repolho não fecha a "cabeça" e as folhas ficam na vertical.

c) $\mathrm{O}$ canteiro de alface apresenta plantas da cultivar Americana, que ressecam as folha na parte inferior e superiores ficam com manchas circulares amarronzadas, com pendoamento e folhas com consistência firme.

d) Alguns frutos de jiló apresentam superfície da casca áspera, sendo abortados logo que ficam com cor preta. As folhas apresentam manchas amareladas e escuras.

e) A vagem apresenta folhas com manchas amareladas.

f) Alguns frutos da pimenteira estão com lagarta na polpa, e algumas plantas estão com folhas ressecadas até morrer.

\section{Solução:}

a) Durante a primavera-verão sob temperaturas e pluviosidade elevadas, o míldio, causado por fungo, causa manchas inicialmente amarelas que ficam pardas, devendo pulverizar com fungicida de ação ampla e utilizar variedades de híbridos resistentes para plantio.

b) A ausência de cabeça no repolho ocorre devido às elevadas temperaturas e pluviosidade durante a primavera-verão, já que a cultura se desenvolve bem durante temperaturas amenas ou frias. Mas o adequado é utilizar uma cultivar de acordo com a época de plantio e fazer as adubações necessárias como a presença do mineral $\mathrm{P}$ (fósforo), que favorece a formação de cabeça, e de $\mathrm{N}$ (nitrogênio) para o crescimento vegetativo.

c) A mancha-de-cercóspora é uma doença fúngica que dissemina facilmente com elevadas temperatura e pluviosidade. As medidas de controle são: aplicação de fungicida; plantar em terreno bem drenado durante o período chuvoso e numa densidade 
que permita uma boa aeração durante o verão; eliminar as folhas baixeiras contaminadas e os restos culturais; evitar adubação com excesso de Nitrogênio; evitar o encharcamento da irrigação; fazer rotação de culturas por um ano com família diferente; plantar variedades adaptadas ao clima da região.

d) A antracnose é uma doença que ocorre quando o clima está quente e alta umidade relativa. O controle pode ser feito através de plantio em áreas mais altas, de menor umidade e afastadas de outras solanáceas hospedeiras; uso de sementes sadias; plantio de cultivares tolerantes a doença; eliminar frutos doentes, partes da planta contaminadas e restos culturais; fazer o raleamento das plantas para permitir aeração; rotação de culturas; aplicação de fungicidas a base de Cobre.

e) As plantas de vagem estão próximas de outras plantas com doenças fúngicas, demonstrando que ocorre a disseminação para as culturas próximas. A aplicação de fungicidas ou produtos naturais como óleo de Neem podem ser utilizados como controle preventivo.

f) A aplicação de inseticidas no início da frutificação previne que os frutos sejam atacados por insetos que ovipositam nos frutos, servindo para entrada de larvas que permanecem no seu interior até que amadureçam, causando perdas de qualidade na comercialização. Já o caso que ocorre a murcha nos períodos do dia mais quentes e morte de algumas plantas mesmo que estejam com muitos frutos e raízes normais, ocorre devido à presença da doença vascular murcha-bacteriana e as práticas de controle são: utilizar áreas para cultivo onde não há encharcamento e histórico da doença; utilizar variedades resistentes; irrigar com água de qualidade e sem excesso; retirar as plantas do local e cobri-lo com cal virgem; higienizar as ferramentas de corte com hipoclorito de sódio; após a poda das plantas aplicar fungicidas à base de Cobre.

Professor Consultado: Prof ${ }^{\circ}$. Dro ${ }^{\circ}$. Diógenes Martins Bardiviesso

\section{Literatura Consultada:}

EMBRAPA ACRE (2002).

EMBRAPA HORTALIÇAS (2007).

EMBRAPA HORTALIÇAS (1998).

EMBRAPA HORTALIÇAS (2012).

FILGUEIRA (2008). 
Conforme os dados apresentados acima sobre os problemas encontrados, a figura 1 apresenta uma representação geral de todas as situações e dos casos mais encontrados.

Figura 1. Quantidade e identificação dos problemas encontrados por meio dos questionários. Cassilândia - MS, 2014.

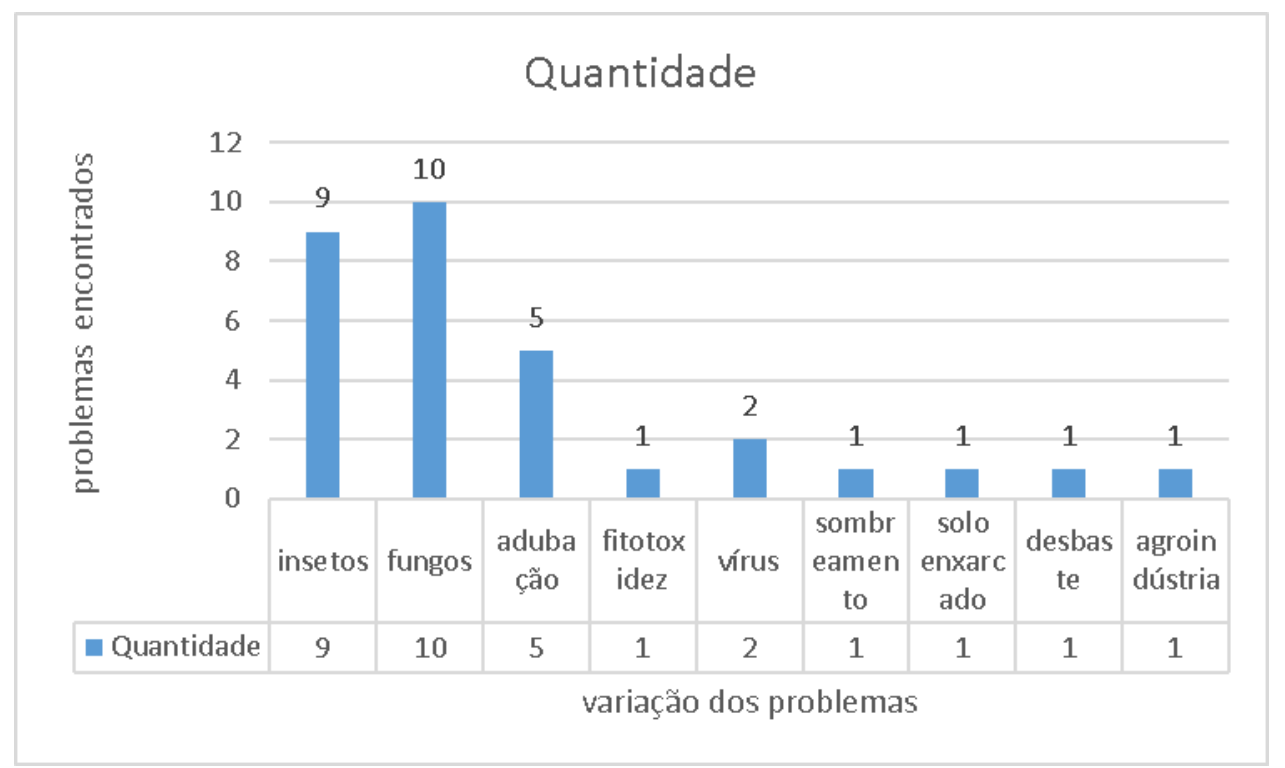

\section{CONCLUSÕES}

As fichas de identificação do produtor preenchidas durante os meses entre agosto e julho dos anos de 2013 a 2014, indicaram situações onde o produtor necessita de assistência técnica de forma contínua e de qualidade, ou seja, orientada por profissionais da área agropecuária, visto que pôde ser proporcionado junto ao Corpo Docente do Curso de Agronomia da Unidade Universitária de Cassilândia com acompanhamento de estudantes voluntários.

Apesar da dificuldade momentânea de solucionar os problemas dos pequenos produtores rurais, os graduandos que participaram puderam vivenciar a realidade desses profissionais e buscar através de pesquisas bibliográficas com apoio de professores da área agronômica, os diagnósticos e as possíveis soluções, acrescentando conhecimento para os futuros agrônomos.

O estudo de um dos casos serviu para analisar a falta de orientação no trabalho de alguns vendedores de verduras e legumes para lidar com os insetos em hortas caseiras na zona urbana, causando o uso incorreto de agrotóxicos em hortaliças 
consumidas frescas, sendo um grave risco para a saúde dos consumidores devido ao poder residual dos inseticidas sintéticos, além da adição de outros produtos tóxicos como hipoclorito de sódio com outros naturais como extrato de fumo, contaminando os alimentos.

Outro caso observado foi em uma propriedade rural próxima ao município de Cassilândia, onde o pomar estava improdutivo apesar da variedade de arbóreas frutíferas e uma terra rica em matéria orgânica, viu-se que a poda com ferramentas sem uma préassepsia, contaminou algumas plantas e os insetos sugadores de seiva passaram a transmitir as doenças entre as plantas, provocando o aborto ou a deformação de frutos, e até a improdutiva de mudas recém transplantas.

A aceitação da assistência técnica foi razoável em virtude das várias informações que os pequenos produtores recebem daqueles que não são profissionais da área, tornando-os resistentes diante dos conhecimentos apresentados durante o trabalho voluntário para minimizar os problemas no campo que causam perdas econômicas na atividade rural de sua sobrevivência, porém, foi entregue um material impresso com a elaboração do diagnóstico na possibilidade de em alguma dúvida por parte do entrevistado ser um meio de consulta.

O uso de métodos alternativos no manejo integrado de pragas e doenças, foi bem aceito pelos produtores, devido ao baixo custo de utilizá-los para o controle e prevenção de patógenos nas culturas, pois algumas matérias-primas como folha de mamoma e fumo, podem ser encontrados no próprio local que desempenham a atividade agrícola.

Os feirantes do município de Cassilândia-MS necessitam de auxílio constante nas atividades agrícolas desde o cultivo até a comercialização.

\section{AGRADECIMENTOS}

À CAPES, pela bolsa concedida e à FUNDECT-MS, pelo apoio financeiro.

\section{REFERÊNCIAS}

AGRONOMIA.NET. Receitas da vovó. Disponível em: < http://www.agronomianet.com.br/receitas_da_vovo_tabelas2.htm>. Acesso em: agosto de 2013. 
ARAÚJO, J. S. P. Diagnóstico e controle de doenças e pragas em orquídeas. UFRGS. 6 de dezembro de 2013. Disponível em:< http://www.orquidario.org/palestras/palestra014.htm>. Acesso em: agosto de 2013.

BRITO, A. A. A. Casa de vegetação com diferentes coberturas: desempenho em condições de verão. Viçosa - MG. 2000. Disponível em: < http://www.ufv.br/dea/ambiagro/arquivos/Tese\%20de\%20Alessandra\%20Brito2000.pdf >. Acesso em: outubro de 2013.

ComoIniciar. Como montar fábrica de geleia de mocotó. Disponível em: <http://www.comoiniciar.com.br/empresa.php?como_montar=fabrica_de_geleia_de_m ocoto>. Acesso em: maio de 2014.

CPT. Orquídeas - combate a pragas e doenças. Viçosa-MG. 2000. Disponível em: <http://www.cpt.com.br/cursos-floricultura-jardinagem/artigos/orquideas-combate-apragas-e-doencas>. Acesso em: dezembro de 2013.

EDUCAÇÃO E CIÊNCIA. Como tratar e prevenir manchas negra em roseiras? Disponível em: <http://www.ehow.com.br/tratar-prevenir-manchas-negras-roseirascomo_137228/>. Acesso em: fevereiro de 2014.

EMBRAPA ACRE. Cultivo de Pimenta Longa na Amazônia Ocidental. Rio Branco AC, 2002. Disponível em:< http://sistemasdeproducao.cnptia.embrapa.br/FontesHTML/Pimenta/Pimenta LonganaAmazoniaOcidental/doencas.htm>. Acesso em: janeiro de 2014.

EMBRAPA. Sistema de Produção de Citros para o Nordeste. Dezembro de 2003. Disponível em : $<$ http://sistemasdeproducao.cnptia.embrapa.br/FontesHTML/Citros /CitrosNordeste/doencas.htm>. Acesso em: dezembro de 2013.

EMBRAPA. Cultivo da Mangueira. Petrolina - PE, 2012. Disponível em: $<$ http://sistemasdeproducao.cnptia.embrapa.br/FontesHTML/Manga/CultivodaMangueir a_2ed/doencas.htm>. Acesso em: fevereiro de 2014 .

Revista Extensão em Foco, nº 13, Jan/ Jul (2017) p. 2 - 22. 
EMBRAPA. Armadilha PET para Captura de Adultos de Moscas-das-Frutas em Pomares Comerciais e Domésticos. Dezembro de 2006. Seropédica-RJ. Disponível em: <http://ainfo.cnptia.embrapa.br/digital/bitstream/CNPAB-2010/34089/1/cit016.pdf>. Acesso: março de 2013.

EMBRAPA HORTALIÇAS. Pimenta (Capsicum spp.). Brasília - DF, 2007. Disponível em:<

http://sistemasdeproducao.cnptia.embrapa.br/FontesHTML/Pimenta/Pimenta_capsicum _spp/pragas.html\#lagartas>. Acesso em: janeiro de 2014.

EMBRAPA HORTALIÇAS. Doenças da Alface. Brasília - DF, 1998. Disponível em: $<$ http://www.infoteca.cnptia.embrapa.br/bitstream/doc/765605/1/CNPHDOCUMENTO S14DOENCASDAALFACEFL07824.pdf>. Acesso em: janeiro de 2014.

EMBRAPA HORTALIÇAS. Doenças e Pragas do Jiloeiro. Brasília - DF, 2012. Disponível em: <http://www.cnph.embrapa.br/paginas/serie_documentos/publicacoes2012/ct_106.pdf>. Acesso em: janeiro de 2014.

EMBRAPA MANDIOCA E FRUTICULTURA. Cajueiro. Perguntas e Respostas: Citrus. Brasília $\quad-\quad$ DF, 2005. Disponível em: < http://ainfo.cnptia.embrapa.br/digital/bitstream/item/101781/1/500perguntascitros.pdf. >. Acesso em: maio de 2014.

EMBRAPA SEMIÁRIDO. Cultivo da Mangueira. Petrolina - PE, 2012. Disponível em: http://sistemasdeproducao.cnptia.embrapa.br/FontesHTML/Manga/CultivodaMangueira _2ed/doencas.htm>. Acesso em: maio de 2014.

EMBRAPA SEMIÁRIDO. Sistema de produção da bananeira irrigada. Porto Velho RO, $2007 . \quad$ Disponível em: <http://sistemasdeproducao.cnptia.embrapa.br/FontesHTML/Banana/BananeiraIrrigada/ pragas.htm>. Acesso em: maio de 2014.

Revista Extensão em Foco, n 13, Jan/ Jul (2017) p. 2 - 22. 
FABRE, N. As razões do fracasso das políticas públicas de desenvolvimento da agricultura familiar na Bacia do Riacho Forquilha - Quixeramobim/ Ceará. Disponível em: <http://www.redereparte.org.br/arquivos/reparte07-082012_110704.pdf>. Acesso em: abril de 2013.

FILGUEIRA, F. A. R. Novo Manual de olericultura. $3^{a}$ edição. Editora UFV. 2008.

GLOBORURAL. Romã atacada por fungos. Junho de 2010. Disponível em: < http://revistagloborural.globo.com/GloboRural/0,6993,EEC1704382-1489-15,00.html>. Acesso em: abril de 2013.

GUILHOTO, J. M.; SILVEIRA, F. G.; ICHIHARA, S. M.; AZZONI, C. R. A importância do agronegócio familiar no Brasil. Revista de Economia e Sociologia Rural. Vol. 44 n³, Brasília, 2006.

JARDINAGEM. Aprenda a combater a cochonilha, uma das pragas mais prejudiciais às plantas ornamentais. Disponível em: < http://mulher.uol.com.br/casa-edecoracao/noticias/redacao/2010/04/06/aprenda-a-combater-a-cochonilha-uma-daspragas-mais-prejudiciais-as-plantas-ornamentais.htm>. Acesso em: fevereiro de 2014.

NOGUEIRA, E. M. C.; FERRARI, J. T. Como cuidar das árvores frutíferas no inverno. São Paulo $\quad-\quad$ SP, $2009 . \quad$ Disponível em: $<$ http://www.biologico.sp.gov.br/artigos_ok.php?id_artigo=108>. Acesso em: maio de 2014.

PEREIRA, W. A. B.; SOUZA, M. O. de; FRANCIS, D. G. O papel dos estudantes de medicina veterinária na orientação de produtores familiares, 2003. Disponível em: $<$ http://www.prac.ufpb.br/anais/Icbeu_anais/anais/trabalho/extencaorural.pdf $>$. Acesso maio de 2013.

PESAGRO-RIO. Empresa de Pesquisa Agropecuária do Estado do Rio de Janeiro. CONTROLE DE PRAGAS DE HORTAS E DE AMBIENTE DOMÉSTICO. novembro/2005. 
RAGA, A.; SOUZA FILHO, M. F. Manejo e monitoramento de moscas-das-frutas. São Paulo - SP, 2007. Disponível em: < http://www.biologico.sp.gov.br/rifib/IIIRifib/4349.pdf>. Acesso em: maio de 2014.

SEVERINO, F. J. A Teoria da Trofobiose. ESALQ. Piracicaba-SP. Novembro de 2001. Disponível em: $<$ http://webcache.googleusercontent.com/search?q=cache:WpGr8RyslmgJ WpGr8RyslmgJ:permacoletivo.files.wordpress.com/2008/05/a-teoria-datrofobiose $. \operatorname{doc}+\& \mathrm{~cd}=3 \& \mathrm{hl}=\mathrm{pt}-\mathrm{BR} \& \mathrm{ct}=\mathrm{clnk} \& \mathrm{gl}=\mathrm{br}>$. Acesso em: abril de 2013.

UNESP. Doenças dos citros. Ilha Solteira - SP, 2007. Disponível em: $<$ http://www.agr.feis.unesp.br/defers/docentes/mpapa/citros>. Acesso em: dezembro de 2013.

VENTURA, T. M.; VIEIRA, F. P.; FILHO, A. S. K.; GUIMARÃES, G. M. A.; VIEIRA, T. R. A importância da diversificação da produção para os pequenos produtores 2012 rurais. Disponível em: <http://www.catagronegocio.com.br/uploads/1/1/7/3/11739052/a_importncia_da_divers ificao_da_produo_para_os_pequenos_produtores_rurais.pdf> Acesso em: abril 2013.

Zamorano, M. S. Montagem e custo de produção para fábrica ou indústria de geleia de mocotó. Mensagem recebida por < msz@engenmax.com> em 5 de março de 2014.

Revista Extensão em Foco, n 13, Jan/ Jul (2017) p. 2 - 22. 